УДК 94 (477.83) (092)

DOI 10.24919/2519-058X.5.116983

Вімалій ТЕЛЬВАК,

orcid.org/0000-0002-2445-968X

доктор історичних наук, професор кафедри всесвітньої історії та спеціальних історичних дисииплін Дрогобицького державного педагогічного університету імені Івана Франка (Україна,

Дрогобич)telvak1@yahoo.com

\title{
ШКОЛА ЧИ ТЕАТР? \\ КУЛЬТУРНА ПОЛІТИКА НА СХІДНОГАЛИЦЬКИХ ЗЕМЛЯХ НА ПОЧАТКУ ХХ сТ. У ДИСКУСІЯХ УКРАЇНСЬКОЇ ІНТЕЛІГЕНЦІї
}

\begin{abstract}
Стаття присвячена реконструкції процесу обговорення в середовищі української інтелігенції Галичини на початку XX ст., иляхів розвитку національної освіти в умовах тиску польської освітньої системи. Проаналізовано аргументи прихильників шкільного (М. Грушевський, I. Франко, I. Труш та С. Чернецький) і театрального (К. Левищький, О. Борковський, Є. Левищький, О. Барвінський) пріоритетів національного поступу.

Ключові слова: театр, гімназія, Східна Галичина, громадська полеміка, М. Грушевський, I. Франко, О. Барвінський.

Jim. 16.
\end{abstract}

Vitaliy TELVAK, Ph D hab. (History), Professor at the Department of World History and Special Historical Disciplines in Drohobych Ivan Franko State Pedagogical University (Drohobych, Ukraine) telvak1@yahoo.com

\section{SCHOOL OR THEATER? \\ CULTURAL POLICY IN EAST GALICIAN LANDS AT THE BEGINNING OF THE $20^{\mathrm{TH}}$ CENTURY IN THE DISCUSSIONS OF UKRAINIAN INTELLIGENCIA}

The article is devoted to the reconstruction of the discussion process in the environment of the Ukrainian intelligentsia of Galicia in the early twentieth century concerning ways of developing the national education under the pressure of the Polish educational system. It is noted that at the turn of the nineteenth and twentieth centuries the biggest challenge for Ukrainians in that region was a very slow growth of the number of educational institutions in comparison with the cultural needs of the population. At that point the situation with the middle schools was particularly deteriorated. It was Hrushevskyi who drew attention to this problem for the first time, pointing out the state of affairs with middle school. The scientist proposed to establish private Ukrainian grammar schools, transferring for this need the funds accumulated for the construction of a national theater in Lviv.

K. Levytskyi, O. Borkovskyi, E. Levytskyi, and O. Barvinskyi did not agree with M. Hrushevskyi, criticizing his idea on the pages of the newspapers «Dilo» and «Ruslan». They drew the community's attention to the loss of reputation from curtailing the initiated national projects. This increased the emotionality of discussing the priorities of national progress: the parties, instead of a rational and thoughtful analysis of the arguments of their opponents, just raised the degree of controversy. Other leaders of the social and cultural life of the region joined the discussion (for example, I. Trush and S. Chernetskyi). The resonance of the discussion is also evidenced by the fact that it ended in the courtroom: the director of the theater M. Gubchak appealed to the editor of «LNV» and, personally, to I. Franko for publications against the construction of the theater, but was no success.

As a result, as is noted, the adherents and opponents of Ukrainian private schooling were judged by life itself: on the eve of the war in Galicia there was an extensive network of secondary schools, which each year produced an increasing number of educated personnel of the national intelligentsia. It became they that were at the forefront of the struggle for the revival of statehood on the Transnistrian lands, and in the interwar period they created an effective resistance to aggressive polonization of the population of the region. Besides, the considerable emotionality of the controversy among the Galician Ukrainians is also emphasized. They were divided into numerous party groups, refusing to carry out a dialogue with their opponents, preferring to profane their vision of the situation rather than to look for the grain of truth in it. This markedly disoriented the entire Ukrainian community, as well as complicated

\footnotetext{
${ }^{1}$ Публікація містить результати досліджень, проведених при грантовій підтримці Держаного фонду фундаментальних досліджень за конкурсним проектом договір Ф77/80-2017 від 31.08.2017 р.
} 
the creation of an effective counterbalance to the Polish domination in the province. The impact this had on the liberation of Galicia should be represented in further researches of the phenomenon of public controversy.

Key words: theater, gymnasium, Eastern Galicia, public polemics, M. Hrushevskyi, I. Franko, O. Barvinskyi.

Ref. 16.

Виталий ТЕЛЬВАК,

доктор исторических наук, профессор кафедры всемирной истории и специиальных исторических дисииплин Дрогобычского государственного педагогического университета имени Ивана Франко (Украина, Дрогобыч) telvak1@yаhoo.com

\section{ШКОЛА ИЛИ ТЕАТР? \\ КУЛЬТУРНАЯ ПОЛИТИКА НА ВОСТОЧНОГАЛИЦКИХ ЗЕМЛЯХ В НАЧАЛЕ ХХ В. В ДИССКУСИЯХ УКРАИНСКОЙ ИНТЕЛЛИГЕНЦИИ}

Статья посвящена реконструкции процесса обсуждения в кругах украинской интеллигенции Галиции в начале XX в. путей развития наиионального образования в условиях давления польской образовательной системы. Проанализированы аргументы сторонников школьного (М. Грушевский, И. Франко, И. Труш и С. Чернецкий) и театрального (К. Левичкий, А. Борковский, Е. Левичкий, А. Барвинский) приоритетов национального прогресса.

Ключевые слова: театр, гимназия, Восточная Галичия, общественная полемика, М. Грушевский, И. Франко, А. Барвинский.

Лит. 16.

Постановка проблеми. Розуміння Галичини як національного П'ємонту, з якого має розпочатися відродження української державності, стало загальновизнаним у середовищі вітчизняної інтелігенції на початку XX ст. 3 огляду на це до Львова спрямовувалися значні інтелектуальні та матеріальні ресурси з обох боків Збруча. Та попри такі потуги, щоразу давалася взнаки виразна скромність фінансових можливостей українців у порівнянні з розмаїттям актуальних національних проектів, що їх продукували тогочасні лідери національного руху. Тож саме життя постійно змушувало вдаватися до селекції запропонованих ініціатив, що зазвичай породжувало доволі емоційні реакції, оскільки зачіпало амбіції їхніх авторів. У цих суперечках виразно проглядалися відмінності в розумінні представниками різних громадсько-політичних осередків пріоритетів поступу національного життя в умовах постійно наростаючого міжнаціонального антагонізму в краї. Привертаючи увагу дослідників до цієї надалі малознаної проблеми, нижче спробуємо реконструювати одну з найбільш голосних на початку XX ст. дискусій, викликану пошуками шляхів виходу української середньої школи з того тупика, в котрому вона опинилася внаслідок тиску домінуючої в Галичині польської освітньої системи.

Аналіз досліджень. Українське шкільництво в галицькому краї за доби автономії протягом тривалого часу є об' єктом спеціальної уваги багатьох дослідників [3; 7; 10]. Натомість, спеціальний аналіз дискусій, котрі породжували проблеми поступу національної школи в колах галицьких інтелектуалів, на сьогодні відсутній. Цим і зумовлена актуальність нашого дослідження.

Метою статті $є$ реконструкція процесу обговорення в середовищі української інтелігенції Галичини на початку XX ст. шляхів розвитку національної освіти в умовах тиску польської освітньої системи.

Виклад основного матеріалу. На зламі XIX - XX ст. чи не найбільшим викликом для українців Галичини було надто повільне зростання кількості навчальних закладів з огляду на культурні потреби населення. При цьому особливо прикрою була ситуація з середньою ланкою освіти. Чи не вперше на це звернув увагу М. Грушевський: у серії статей на сторінках редагованого ним «Літературно-наукового вістника» («Що ж далі? В справі руських гімназій», «В справі руських шкіл і руського театру» та «Не даймося») учений вказав на загрозливий для модерного українства стан справ із середнім шкільництвом. Ілюструючи цю небезпеку, М. Грушевський наводить промовисті цифри державної статистики - 3 початком 1903 - 1904 начального року на Східну Галичину, заселену на 70\% українцями, припадало 25 польських гімназій, 4 українські, 2 німецькі. Таким 
чином, робить учений вражаючі висновки: корінна українська більшість Східної Галичини, яка переважає кількість поляків у чотири рази, має україномовних середніх шкіл у шість разів менше, ніж поляки краю. При цьому одна польська середня школа припадає приблизно на 30 тисяч польського населення, тоді як одна українська - на 820 тисяч українців $[4,513]$.

Осмислюючи проблеми розвитку середньої ланки українського шкільництва, М. Грушевський, як і належить історику, сягає генези шкільного питання в Австро-Угорській імперії. Він відзначає, що необхідність націоналізації школи в інтересах культурного розвитку українського населення Галичини усвідомлювалася вже при першому пробудженні націй краю. У 1848 р. ця свідомість виявилася з особливою силою, і зроблені в цьому сенсі подання уряду мали наслідком розпорядження від 4 грудня 1848 р., яке проголошувало, що німецька викладова мова у гімназіях української частини Галичини зберігається тимчасово, поки наявність викладачів, що володіють українською мовою, не дасть можливості запровадити нею повноцінне викладання. Однак це рішення залишилося на рівні декларації - уряд нічого не зробив для зростання української вчительської верстви, і гімназії зберегли свій переважно німецький характер аж до конституційної ери 1867 р., коли було визнано права народностей держави на націоналізацію школи. Втім, у цей час центральний уряд визнав гегемонію польської шляхти в Галичині. В результаті, при зміні німецького викладання в школах Галичини місцевими мовами лише одна - давня академічна гімназія Львова - отримала право на викладання українською мовою, в інших було запроваджено польську мову навчання.

Це надбання польська влада краю поквапилася закріпити за собою статутом, прийнятим Галицьким сеймом. На підставі цього статуту, що цілковито суперечив загальнодержавним законам, запровадження на майбутнє української мови у викладанні будь-якої гімназії чи реального училища або відкриття середнього навчального закладу з викладанням українською мовою могло здійснитися не інакше, як за особливою постановою сейму, якій мав ще передувати сприятливий відгук місцевої повітової ради [7, 269-276]. Цей безпрецедентний за своїм правовим свавіллям статут був єдиним у своєму роді у всій імперії і вочевидь суперечив конституції, що, втім, не перешкоджало його функціонуванню аж до початку Першої світової війни. Механізм дії статуту був зрозумілий: Галицький сейм, в якому виборча система забезпечувала переважну більшість представникам польської народності, став, як писав М. Грушевський, «владним охоронцем панування польської мови в середній школі», адже «він може накласти veto на будь-яку спробу уряду зробити щось для русинської народності в цій сфері» $[4,508]$. Таким чином, польська меншість краю отримала важелі суттєво гальмувати культурний і освітній поступ українців Галичини.

Ті широкі права, які давав закон 1867 р., польське суспільство і його сеймові представники використали надзвичайно повно. Хоча середні навчальні заклади в імперії відкривав уряд на кошти державного бюджету, поляки все робили для того, щоб без їхнього дозволу це не відбувалося і «обмінювали» кожну поступку в освітній сфері на суттєві обмеження прав українців в інших важливих напрямах національного життя. Інструментом цієї політики була Крайова шкільна рада - вища освітня адміністрація краю, майже цілковито сформована з поляків. Її постановою було вирішено, що українські навчальні заклади можна засновувати лише в містах, де вже є такі самі польські. Також українські середні навчальні заклади спочатку засновувалися у вигляді паралельних класів польських шкіл, а вже згодом, перейшовши різні труднощі, їм давалися самостійні організаційні права.

Викриваючи задум польської адміністрації, М. Грушевський так характеризував описану ситуацію: «Цей принцип, абсолютно нераціональний з педагогічної точки зору, оскільки створює конкуруючі школи в одній і тій же місцевості замість того, аби засновувати їх у місцевостях, взагалі позбавлених середньої школи, має на меті не допустити, щоб поляки і євреї за відсутності польського навчального закладу віддавали своїх дітей у русинський, де вони мусили б навчатися по-українські й піддатися українізації, як були змушені піддатися полонізації русинські та єврейські діти в польських середніх навчальних закладах» [4, 509]. Ці проблеми М. Грушевський докладно проілюстрував на прикладі тих надзвичайних труднощів, що їх польська адміністрація краю чинила у справі відкриття перших українських гімназій в Перемишлі, Коломиї, Тернополі. 
3 огляду на вищеописану ситуацію, М. Грушевський одним із перших у Галичині ще на зламі XIX - XX ст. подав голос у справі заснування приватних українських гімназій. Він був переконаний, що тільки таким шляхом можна повноцінно розбудувати середню ланку школи, вільну від посягань польських галицьких шкільних властей, а також залучити до праці кращих українських педагогів, забезпечивши тим самим новий напрям виховання. «Відкриваючи свої приватні школи, - писав він, - ми ставимо справді нерукотворний пам'ятник, скріплюємо себе як народ, виховуємо для себе власну інтелігенцію» [5, 205].

Усвідомлюючи розмір видатків на свій проект, як і загальну незасібність українського населення краю, М. Грушевський запропонував на цю шляхетну справу спрямувати кошти, котрі тривалий час акумулювалися для побудови національного театру у Львові. Втім, далеко не всі представники українського політикуму в Галичині визнали рацію голові НТШ. Побудова театру, на котрий поляки блокували виділення державних коштів, вважалася справою національної честі, тож ще на початку 1890-х рр. було кинуто клич, щоб українці краю складали пожертви на цю справу. За десять років вдалося зібрати значну суму, і справа перейшла в практичну площину. Визнаючи важливість і цієї ділянки культурної роботи, М. Грушевський водночас наполягав на значно більшій актуальності організації приватного шкільництва. Вчений слушно зауважив, що неписьменні та некультурні громадяни не потребуватимуть театру, отже, найперше завдання побороти високий рівень анальфабетизму в краї - один з найбільших серед населення АвстроУгорської імперії. Цією ініціативою, за словами Олександра Борковського, львівський професор «з'єлєктризував нашу суспільність» $[2,2]$.

3 цими думками видатного педагога не погодилися деякі очільники галицьких українців, розкритикувавши ідею М. Грушевського на сторінках газети «Діло». У своїй «Заяві», поділивши занепокоєння львівського професора стосовно надто повільних темпів заснування нових українських гімназій, вони звернули увагу громади на репутаційних втратах від згортання розпочатих національних проектів. У згаданій «Заяві», зокрема, наголошувалося, що «безнастанне висуванє нових проектів на перше місце з усуванєм змагань уже розпочатих, уважаємо за річ неодвітну а навіть шкідливу загальній справі народній [...], що в теперішній ситуації є найпильнішою справа будови руского театру у Львові» $[9,1]$.

До цієї заяви критично поставився тогочасний однодумець М. Грушевського та співредактор «ЛНВ» Іван Франко. Беззастережно підтримавши колегу, галицький поет взагалі відмовив ідеї побудови українського театру в столиці краю у будь-якій доцільності. На його переконання, українське театральне середовище ще не сформоване, а практика театральних гастролей передбачає значну мобільність українських труп. Тож збудований театр, наголошує I. Франко, мав би здебільшого стояти пусткою, породжуючи фінансовий дефіцит на його утримання, а витрачені на цю справу кошти пішли б фактично намарно [14, 122-132].

Емоційний виступ I. Франка змусив реплікувати оборонців побудови українського театру у Львові. Вкотре на підтримку цієї ідеї в своєму зверненні на сторінках «Діла» виступив один iз лідерів галицького політикуму Кость Левицький. Показавши непослідовність I. Франка, котрий на початку століття виступав гарячим прихильником творення «театрального фонду», дописувач знову наголосив на потребі завершення розпочатих національних проектів. У підсумку, К. Левицький закликав «не шкодити розпочатому ділу; бо як зачнемо розсівати завше нові проекти і перебивати розпочаті, то жадного з них не виконаємо і доведемо до безголов'я» $[9,1]$.

Наведені аргументи на сторінках того ж таки «Діла» поглибив інший знаний галицький діяч Євген Левицький. Він також висловив здивування від тези I. Франка про нерозвиненість українського театрального мистецтва, слушно зауваживши, що саме побудова театру стане каталізатором якісних змін у цій галузі. Погодившись із вагомістю справи закладання українських приватних гімназій, як зрештою й багатьох інших національних проектів, дописувач наголосив на потребі відповідального ставлення до доручень, котрі громада дає своїм очільникам. «Збираймо гроші на ріжні ціли, - закликав Є. Левицький, - ставмо собі тих цілий як найбільше, аби лише виходили вони з наших народних потреб, а від сего наша національна справа тілько виграє, бо причиниться до всесторонного розвитку нашого національного елементу» $[8,1]$. 
На жаль, згадані вище виважені заяви не зупинили емоційного обговорення пріоритетів національного поступу. Сторони, замість раціонального та вдумливого аналізу аргументів опонентів, ще більше підняли градус полеміки, до якої долучилися й інші представники громадського та культурного життя краю. Вкотре на сторінках «ЛНВ» і того ж таки «Діла» пріоритетність шкільної справи піднесли I. Франко [13; 15], I. Труш [12] та С. Чернецький [16]. Про резонансність обговорення свідчить і те, що вона закінчилася у судовій залі: тогочасний директор театру М. Губчак оскаржив редакцію «ЛНВ» і особисто I. Франка за публікації у справі побудови театру і програв.

Відзначимо, що поряд із «театральним» аргументом, висувалися й суто економічні розрахунки на адресу проекту М. Грушевського. 3 цього погляду йому найбільш запально опонували О. Борковський та О. Барвінський. Так, останній вказував, що східногалицька громада занадто фінансово незасібна, щоб утримувати свої середні школи та фактично висміяв проект М. Грушевського як популістський $[1,3]$. Ще більш відверто на нереальності фінансових розрахунків львівського професора лідер галицьких народовців зупинився в своїх «Споминах»: «Перепони, з якими з боку соймової польської більшости а вчасти і правительства стрічалися наші змагання до заснування українських шкіл, спонукали проф. М. Грушевського виступити в Л. Н. Вістнику з покликом до засновування приватних укр[аїнських] гімназій. Гадка сама про себе теоретично добра і популярна і наша суспільність приняла іiі дуже радо, не розібравши всіх з такими змаганнями звязаних тягарів, які через те спадали на наше незасібне громадянство. [...] Се спонукало мене в «Руслані» $[\ldots]$ в передовиці виступити з конкретним поясненнєм того оклику киненого проф. Грушевським $[\ldots] \gg[6,511]$.

Висновки. У підсумку відзначимо, що прихильників і противників українського приватного шкільництва розсудило саме життя - напередодні війни у Галичині діяла розгалужена мережа середніх навчальних закладів, котрі щороку продукували дедалі більшу кількість освічених кадрів національної інтелігенції. Саме вони стали в авангарді боротьби за відродження державності на Наддністрянських землях, а в міжвоєнний час створили дієвий спротив агресивній полонізації населення краю. Водночас, відзначимо значну емоційність полеміки в середовищі галицьких українців. Поділені на численні партійні групи, тогочасні лідери фактично відмовлялися від діалогу з опонентами, воліючи профанувати їхнє бачення ситуації, аніж шукати в ньому бодай зерна істини. Це помітно дезорієнтувало всю українську громаду, як і ускладнювало створення дієвої противаги польській домінації в краю. Який це мало вплив на долю Визвольних змагань у Галичині, мають показати подальші дослідження феномену громадської полеміки.

\section{СПИСОК ВИКОРИСТАНИХ ДЖЕРЕЛ І ЛІТЕРАТУРИ}

1. [Барвінський О.] Справа приватних гімназій (з нагоди статї проф. Грушевского: Щож далї? в І. кн. Лїтерат. наук. Вістника за 1905) / Олександр Барвінський / Олександр Барвінський // Руслан. - 1905. Ч. $84 .-$ C. 3-4.

2. Борковський Ал. В справі закладання приватних руских гімназій / Олександр Борковський / Александр Борковський // Дїло. - 1905. - Ч. 9. - С. 1-2.

3. Герасименко С. Науково-педагогічна та просвітницька діяльність Михайла Грушевського (1894 1917 рр.): монографія / Світлана Герасименко. - Дрогобич: Редакційно-видавничий відділ Дрогобицького державного педагогічного університету імені Івана Франка, 2013. - 214 с.

4. Грушевський М. Із польсько-українських стосунків Галичини / Михайло Грушевський // Грушевський М.С. Твори: У 50 т.; / Редкол.: П. Сохань, Я. Дашкевич, І. Гирич та ін.; Голов. ред. П. Сохань. - Львів: Світ, 2002. - Т. 1: Серія «Суспільно-політичні твори (1894 - 1907)». - С. 485-527.

5. Грушевський М. Українські приватні школи / Михайло Грушевський // Календар «Просвіти» на 1911 р. - Львів, 1910. - С. 195-207.

6. Інститут літератури НАН України ім. Т. Шевченка. - Ф. 135. - Спр. 48. - На 531 арк.

7. Кошелєва Н. Діяльність галицької Крайової шкільної ради стосовно української народної освіти в 1873 - 1914 роках / Н. Кошелєва // Вісник Львівського університету. Серія історична. - Львів: ЛНУ ім. Ів. Франка, 1999. - Вип. 34. - С. 269-276.

8. [Левицький С.]. Чи театр, чи що інше? / Євген Левицький // Діло. - 1905. - Ч. 26. - С. 1.

9. Левицький К. Борба за народний театр / Кость Левицький // Діло. - 1905. - Ч. 30. - С. 1. 
10. Тельвак В. Громадсько-політична діяльність Михайла Грушевського в Галичині в оцінках сучасників / Віталій Тельвак // Annales Universitatis Mariae Curie-Sklodowska. Sectio F. - Lublin, 2016. - Vol. LXXI. S. $65-88$.

11. Труш І. Новий театральний будинок і вигляди на будуче / Іван Труш // Артистичний Вістник. 1905. - Ч. 4-5.

12. Труш І. Проект українського театру у Львові / Іван Труш // Артистичний Вістник. - 1905. - Ч. 2, 3.

13. Франко І. Замість дискусії - цьвітки полеміки / Іван Франко // Літературно-науковий вістник. 1905. - Кн. III. - C. 221-237.

14. Франко І. Львівський театр і народна честь / Іван Франко // Літературно-науковий вістник. - 1905. Кн. II. - C. 122-132.

15. Франко I. Наша театральна мізерія / Іван Франко // Артистичний вісник. - Львів, 1905. - С. 90-91.

16. Чернецький С. Дещо про теперішній стан галицько-руського театру / С. Чернецький // Літературно-науковий вістник. - 1905. - Кн. IV. - С. 56-64.

\section{REFERENCES}

1. [Barvinskyi O.] Sprava pryvatnykh himnazii (z nahody stati prof. Hrushevskoho: Shchozh dali? v I. kn. Literat. nauk. Vistnyka za 1905) / Oleksandr Barvinskyi / Oleksandr Barvinskyi // Ruslan. - 1905. - Ch. 84. - S. 3-4.

2. Borkovskyi Al. V spravi zakladannia pryvatnykh ruskykh himnazii / Oleksandr Borkovskyi / Aleksandr Borkovskyi // Dilo. - 1905. - Ch. 9. - S. 1-2.

3. Herasymenko S. Naukovo-pedahohichna ta prosvitnytska diialnist Mykhaila Hrushevskoho (1894 1917 rr.): monohrafiia / Svitlana Herasymenko. - Drohobych: Redaktsiino-vydavnychyi viddil Drohobytskoho derzhavnoho pedahohichnoho universytetu imeni Ivana Franka, 2013. - 214 s.

4. Hrushevskyi M. Iz polsko-ukrainskykh stosunkiv Halychyny / Mykhailo Hrushevskyi // Hrushevskyi M.S. Tvory: U 50 t.; / Redkol.: P. Sokhan, Ya. Dashkevych, I. Hyrych ta in.; Holov. red. P. Sokhan. - Lviv: Svit, 2002. - T. 1: Seriia «Suspilno-politychni tvory (1894-1907)». - S. 485-527.

5. Hrushevskyi M. Ukrainski pryvatni shkoly / Mykhailo Hrushevskyi // Kalendar «Prosvity» na 1911 r. Lviv, 1910. - S. 195-207.

6. Instytut literatury NAN Ukrainy im. T. Shevchenka. - F. 135. - Spr. 48. - 531 ark.

7. Koshelieva N. Diialnist halytskoi Kraiovoi shkilnoi rady stosovno ukrainskoi narodnoi osvity v 1873 1914 rokakh / N. Koshelieva // Visnyk Lvivskoho universytetu. Seriia istorychna. - Lviv: LNU im. Iv. Franka, 1999. - Vyp. 34. - S. 269-276.

8. [Levytskyi Ye.]. Chy teatr, chy shcho inshe? / Yevhen Levytskyi // Dilo. - 1905. - Ch. 26. - S. 1.

9. Levytskyi K. Borba za narodnyi teatr / Kost Levytskyi // Dilo. - 1905. - Ch. 30. - S. 1.

10. Telvak V. Hromadsko-politychna diialnist Mykhaila Hrushevskoho v Halychyni v otsinkakh suchasnykiv / Vitalii Telvak // Annales Universitatis Mariae Curie-Skiodowska. Sectio F. - Lublin, 2016. - Vol. LXXI. - S. 65-88.

11. Trush I. Novyi teatralnyi budynok i vyhliady na buduche / Ivan Trush // Artystychnyi Vistnyk. - 1905. Ch. 4-5.

12. Trush I. Proekt ukrainskoho teatru u Lvovi / Ivan Trush // Artystychnyi Vistnyk. - 1905. - Ch. 2, 3.

13. Franko I. Zamist dyskusii - tsvitky polemiky / Ivan Franko // Literaturno-naukovyi vistnyk. - 1905. Kn. III. - S. 221-237.

14. Franko I. Lvivskyi teatr i narodna chest / Ivan Franko // Literaturno-naukovyi vistnyk. - 1905. - Kn. II. S. 122-132.

15. Franko I. Nasha teatralna mizeriia / Ivan Franko // Artystychnyi visnyk. - Lviv, 1905. - S. 90-91.

16. Chernetskyi S. Deshcho pro teperishnii stan halytsko-ruskoho teatru / S. Chernetskyi // Literaturnonaukovyi vistnyk. - 1905. - Kn. IV. - S. 56-64.

Стаття надійшла до редакиії 20.10.2017 p. 